Article

\title{
Reproductive Biology of Puntius sophore in Bangladesh
}

\author{
Tajmira Hasan ${ }^{1}$, Md. Foysul Hossain ${ }^{1}$, Md. Mamun ${ }^{1}$, Md. Jahangir Alam ${ }^{1}$ \\ Mohammad Abdus Salam ${ }^{2}$ and S. M. Rafiquzzaman ${ }^{1, *}$
}

1 Department of Fisheries Biology and Aquatic Environment, Bangabandhu Sheikh Mujibur Rahman Agricultural University, Gazipur 1706, Bangladesh; mira0017@gmail.com (T.H.);

foysulbokul1994@gmail.com (M.F.H.); mamun1006001@gmail.com (M.M.);

mjalam.bsmrau@gmail.com (M.J.A.)

2 Department of Genetics and Fish Breeding, Bangabandhu Sheikh Mujibur Rahman Agricultural University, Gazipur 1706, Bangladesh; salam_aqua@yahoo.com

* Correspondence: rafiquzzaman@bsmrau.edu.bd

Received: 19 March 2018; Accepted: 4 June 2018; Published: 11 June 2018

\begin{abstract}
Pool barb (Puntius sophore) is an important small indigenous species of Bangladesh, belonging to the family Cyprinidae of the order Cypriniformes. The main objectives of the present study were to identify the breeding season of Pool barb through observation of the gonadosomatic index (GSI), fecundity, oocytes diameter, and gonadal histology of the species. GSI was calculated and fecundity was determined by the gravimetric method. Interestingly, the highest value of GSI was $15.43 \pm 2.20$ for the month of April at Gazipur while it was $15.60 \pm 1.74$ in June for Jessore. In Gazipur, the highest fecundity ( $5053 \pm 878.27)$ was recorded in the month of April and the highest fecundity $(5433 \pm 968.26)$ was recorded in the month of June for Jessore. Histology of the ovary of Pool barb shows the presence of early and late perinucleolar stage of oocytes during March indicating immature oocyte. Histological data revealed that the spawning season of Pool barb starts from March to July with a peak during April to May for Gazipur region and May to July for Jessore region. Finally, these results can be concluded that breeding season may vary from region to region due to environmental as well as other factors.
\end{abstract}

Keywords: Puntius sophore; gonadosomatic index; fecundity; histology

\section{Introduction}

Freshwater fish species are in different levels of threat in Bangladesh, such as Threatened (25\%), Critically Endangered (3\%), Endangered (12\%), Vulnerable (10\%), Near Threatened (11\%), Least Concern (48\%), and Data Deficient (16\%) [1,2]. Puntius sophore is under the Least Concern category.

The common name of $P$. sophore is pool barb or spot fin swamp barb or stigma barb, which has a wide geographical distribution in India, Bangladesh, Myanmar, Nepal, Pakistan, China [3], Bhutan and Afghanistan [4]. The major habitats of $P$. sophore are rivers, streams, ponds, beels, floodplains, baors, and haors [5,6]. This species matures in a year and breeds naturally in freshwater during monsoon [7]. The species has high economic value due to its nutritive status; ornamental value and market demand both as fresh and processed products [8]. It has great importance for small-scale fishers in Bangladesh [9,10]. Previous studies [11-13] reported that it is an important food resource and a crucial source of micronutrients that prevents malnutrition, vitamin and mineral deficiencies in rural communities, especially for vulnerable groups such as poor women and children in Bangladesh. Moreover, it has been used as an aquarium fish [14]. This species is also used to make fermented type products like Shidol. However, the abundance of $P$. sophore from natural resources are diminishing rapidly because 
of heavy fishing. Knowledge of fecundity, the gonadosomatic index (GSI) and observation of gonadal development are important for the proper management of $P$. sophore. The management of a species is easier by knowing the gonadal development and spawning season of that species. Studies on reproductive physiology can provide important and basic information on the gonadal maturity, breeding potential, and breeding season of a species. In a fishery, histology serves as a useful index of biological cycle viz., gonadal development and spawning. In addition, fecundity data as a biological parameter helps to assess abundance reproductive potential and to evaluate the commercial potentiality of a fish stock. GSI helps in understanding the maturity stage and exact time of spawning [15]. Gonadal maturation represents a series of cyclic morphological changes, where the gonads undergo gradual growth and ripeness. Keeping in view the importance of the above biological parameters in determining the reproductive success and formulating management strategies, a study was undertaken to determine the fecundity, GSI, and ovarian development through histology of $P$. sophore. These data are also important for increasing the aquaculture production of $P$. sophore.

In Bangladesh, very few studies on some aspects of the reproductive biology of small fishes are available. Studies on the reproductive biology of $P$. sophore are not available from Bangladesh. Therefore, the target of the current study was to determine GSI, fecundity, and the oocytes diameter of P. sophore.

\section{Results and Discussion}

\subsection{Calculation of Total Length, Body Weight, and Ovary Weight of P. sophore}

The total length of $P$. sophore collected from the study area during January to September 2016 was measured. Total lengths ranged from $6.9 \pm 0.65 \mathrm{~cm}$ to $10.06 \pm 0.59 \mathrm{~cm}$. The ovary weight ranged from $0.0104 \pm 0.01 \mathrm{~g}$ to $2.0183 \pm 0.46 \mathrm{~g}$. For the sample collected from Gazipur, the highest length $(10.06 \pm 0.59 \mathrm{~cm})$ and ovary weight $(2.0183 \pm 0.46 \mathrm{~g})$ were found in April. In the case of Jessore, the highest length $(9.93 \pm 0.23 \mathrm{~cm})$ and ovary weight $(1.61 \pm 0.28 \mathrm{~g})$ were found in June and in both areas lowest values for length and ovary weight were found in September, as shown in Tables 1 and 2.

In Gazipur, body length, body weight, and ovary weight are highest in April, and in Jessore, body length, body weight, and ovary weight are highest in June. Regression analysis showed that there is a linear relationship in term of length and mass. It has also found that there is a remarkable variation for the highest value in Gazipur and Jessore, this is because of the effect of water quality parameters, nutrients, and food availability $[8,16]$.

Table 1. Mean and standard deviation $( \pm S D)$ of total length, body mass, and ovary mass in female P. sophore in Gazipur.

\begin{tabular}{ccccc}
\hline \multirow{2}{*}{ No. of Fish Examined } & \multicolumn{3}{c}{ Mean and Standard Deviation ( \pm SD) } \\
\cline { 3 - 5 } & & Total Length $(\mathbf{c m})$ & Body Mass (g) & Ovary Mass (g) \\
\hline January & 20 & $7.43 \pm 0.29$ & $7.83 \pm 0.49$ & $0.0104 \pm 0.01$ \\
February & 20 & $7.42 \pm 0.30$ & $7.89 \pm 0.58$ & $0.0352 \pm 0.01$ \\
March & 20 & $8.72 \pm 0.39$ & $9.23 \pm 0.77$ & $0.6758 \pm 0.09$ \\
April & 20 & $10.06 \pm 0.59$ & $13.0 \pm 1.84$ & $2.0183 \pm 0.46$ \\
May & 20 & $9.42 \pm 0.46$ & $12.06 \pm 0.87$ & $1.842 \pm 0.24$ \\
June & 20 & $8.96 \pm 0.58$ & $10.07 \pm 1.68$ & $1.153 \pm 0.24$ \\
July & 20 & $7.81 \pm 0.31$ & $9.54 \pm 0.84$ & $0.9478 \pm 0.22$ \\
August & 20 & $6.9 \pm 0.65$ & $7.355 \pm 1.64$ & $0.1697 \pm 0.03$ \\
September & 20 & & & \\
\hline
\end{tabular}


Table 2. Mean and standard deviation $( \pm S D)$ of total length, body weight and ovary weight in female P. sophore in Jessore.

\begin{tabular}{ccccc}
\hline & No. of Fish Examined & \multicolumn{3}{c}{ Mean \pm SD } \\
\cline { 3 - 5 } & & Total Length $\mathbf{( c m )}$ & Body Weight (g) & Ovary Weight $(\mathbf{g})$ \\
\hline January & 20 & $7.08 \pm 0.17$ & $7.2 \pm 0.39$ & $0.033 \pm 0.02$ \\
February & 20 & $6.99 \pm 0.46$ & $7.19 \pm 0.58$ & $0.034 \pm 0.02$ \\
March & 20 & $7.22 \pm 0.38$ & $7.55 \pm 0.86$ & $0.71 \pm 0.16$ \\
April & 20 & $7.98 \pm 0.57$ & $8.19 \pm 0.63$ & $0.88 \pm 0.26$ \\
May & 20 & $8.46 \pm 0.30$ & $8.99 \pm 0.33$ & $1.126 \pm 0.15$ \\
June & 20 & $9.93 \pm 0.23$ & $10.32 \pm 0.85$ & $1.61 \pm 0.28$ \\
July & 20 & $7.88 \pm 0.42$ & $9.28 \pm 0.48$ & $1.24 \pm 0.11$ \\
August & 20 & $7.07 \pm 0.38$ & $7.34 \pm 1.29$ & $0.178 \pm 0.07$ \\
September & 20 & $7.2 \pm 1.15$ & $0.166 \pm 0.05$ \\
\hline
\end{tabular}

\subsection{Analysis of Gonadosomatic Index of P. sophore}

The GSI is the main indicator to know about the status of gonadal development and the maturity of individuals. GSI was calculated for female P. sophore during January to September 2016 for the sample collected from both Gazipur and Jessore. In Gazipur, the highest GSI was found in April (15.43 \pm 2.20$)$ and the lowest GSI was found in January $(0.65 \pm 0.08)$, whereas for the sample collected from Jessore, the highest GSI was found in June $(15.60 \pm 1.74)$ and the lowest GSI was found in January $(0.458 \pm 0.31)$ (Figure 1).

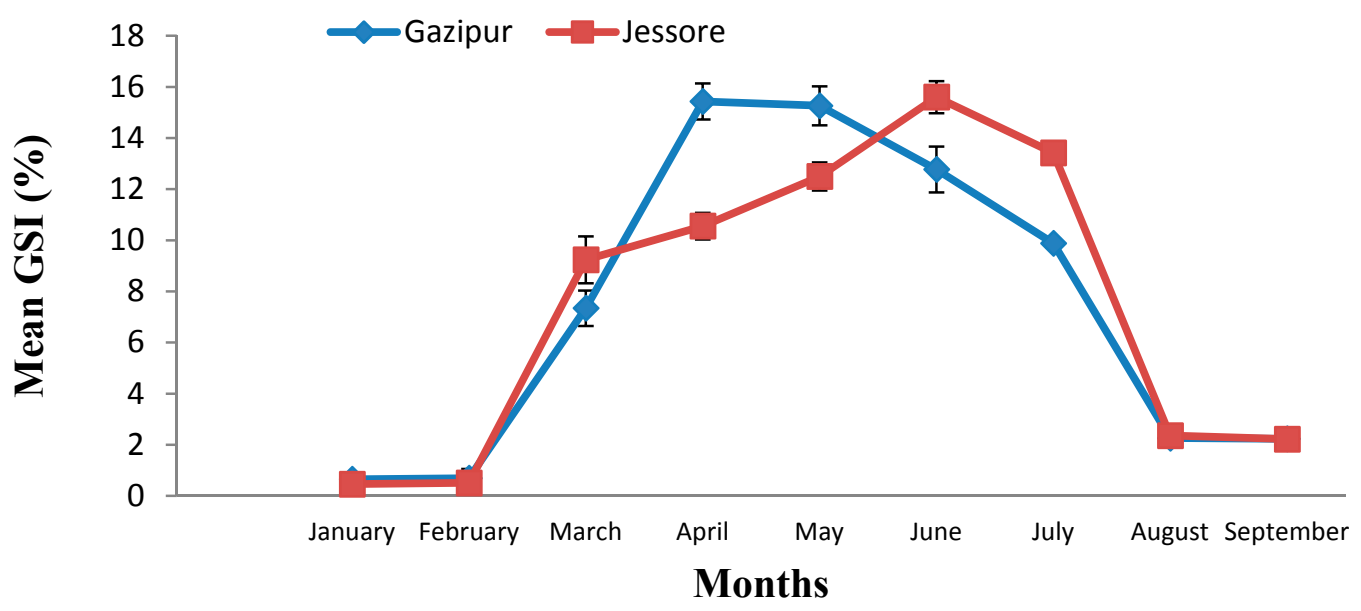

Figure 1. Monthly mean \% of gonadosomatic index (GSI) of P. sophore in Gazipur and Jessore.

The results showed there was a significant variation in terms of GSI between two regions among different months $(p<0.05)$. There was a sudden rise in the value of GSI in March, which continues till July. The mean GSI values throughout the nine months study period showed the existence of one breeding season in P. sophore from March to July. In Gazipur, the highest GSI was found in April, whereas the highest GSI was found in June for Jessore. These findings agree with the findings of Choudhury et al., who studied the breeding biology of P. sophore and reported that the increases in GSI correspond to increased gonadal development, which is between March to July and followed by a gradual decrease in value after July [17]. Other species of genus Puntius have a prolonged spawning period (April to August) with a peak during the rainy season [18]. Hossain et al. studied with P. sophore and found the highest GSI value was in July [19]. There was variation in terms of GSI in both the Gazipur and Jessore districts. The reason may be due to changes in environmental parameters.

The GSI showed a single highest peak during the months of March to July, thereby indicating that a greater percentage of fish were maturing during this period. The sudden drop of GSI during 
the month of August clearly suggested the onset of spawning activity in this fish, indicating that the fish had a definite breeding season in a year. Similar results were reported for Rasbora rasbora by Agarwal and showed the highest value of GSI for the month of July and a sudden drop in the month of August [20]. Kant et al. reported that the GSI showed a single highest peak of P. sophore $14.06 \pm 1.59$ during the month of July, thereby indicating that a greater percentage of fish were maturing during this period [21].

\subsection{Calculation of Fecundity of P. sophore}

Successful fisheries management, including practical aquaculture, relies on having an accurate assessment of fecundity to understand the recovery ability of fish populations $[15,22]$. The result showed that the highest fecundity was found in April (5053 \pm 878.265) for the sample collected from Gazipur, having a total length $10.06 \mathrm{~cm}$ and body weight $13 \mathrm{~g}$ and in the case of Jessore the highest fecundity was found in June (5433 \pm 968.255$)$, having a total length $9.93 \mathrm{~cm}$ and a body weight $10.32 \mathrm{~g}$. The lowest fecundity was found in the month of September for both the study areas (Table 3). Tareque et al. reported that fecundity of $P$. sophore varied from 743 oocytes $(7.00 \mathrm{~cm}$ Total Length (TL), mass $5.3 \mathrm{~g}$ ) to 4013 oocytes ( $9.90 \mathrm{~cm}$ TL, mass $14.3 \mathrm{~g}$ ) in the Mouri River, Khulna, southern Bangladesh, which is similar to the present study [23]. Bithy et al. estimated a range of 7951 to 23,053 oocytes for a corresponding body mass of 10.12 to $26.5 \mathrm{~g}$, which is a little contradiction with our findings [24]. This may be due to various reasons including habitat, environmental factors, and food availability.

Table 3. Mean and standard deviation $( \pm \mathrm{SD})$ of the fecundity of $P$. sophore in Gazipur and Jessore.

\begin{tabular}{ccc}
\hline \multirow{2}{*}{ Month } & \multicolumn{2}{c}{ Fecundity (Mean \pm SD) } \\
\cline { 2 - 3 } & Gazipur & Jessore \\
\hline March & $2601 \pm 333.37$ & $1870 \pm 272.84$ \\
April & $5053 \pm 878.26$ & $2328 \pm 193.00$ \\
May & $4550 \pm 345.86$ & $3550 \pm 547.2$ \\
June & $2659 \pm 570.52$ & $5433 \pm 968.25$ \\
July & $2764 \pm 394.25$ & $4032 \pm 622.68$ \\
August & $523 \pm 169.23$ & $735 \pm 87.18$ \\
September & $616 \pm 77.56$ & $516 \pm 175.23$ \\
\hline
\end{tabular}

\subsection{Oocyte Diameter of P. sophore}

Oocyte diameter was estimated to observe spawning frequency of P. sophore. In Gazipur, the highest oocyte diameter was found in April $(0.79 \pm 0.032 \mathrm{~mm})$ and in the case of Jessore the highest oocyte diameter was found in June $(0.72 \pm 0.038 \mathrm{~mm})$. The lowest oocyte diameter was found in the month of September for both the study areas (Table 4). The ovum was an almost oval shape in the mature stage. The mean oocyte diameter increased with the maturational stage of the ovary of P. sophore. The oocyte diameter progressively increased from March to July, along with the progression of the maturity phase [25]. Chakraborty et al. reported that the egg diameter of Puntius sarana was significantly higher in the month of June, where the diameter of the ova was decreased was in the month of October, which indicates that the diameter of the ova was highest in the peak spawning season [26]. The mass of ovary followed regular cyclic changes, which are found to be correlated with the development activity in the gonads [26]. Oocytes of different sizes were found at the same time, which indicates that $P$. sophore is an asynchronous spawner with a prolonged breeding season. A positive relationship occurred between mean GSI and oocyte diameters. This finding agrees with the findings of Alam et al. For two freshwater barbs, P. sophore and Puntius ticto [27].

\subsection{Annual Changes in the Ovary}

The ovary of the female P. sophore was bi-lobed elongated and situated in the body cavity. The shape, size, and color of the ovary varied considerably according to the degree of the maturation 
stage of the oocytes. The body cavity size and occupancy varied depending on the stage and condition of sexual maturity of the female. The color of the ovary and diameter of the ovum was used to know the developmental stages of the ovary. At the immature stage, the ovaries were transparent and irregular in shape. At maturing stage, the ovary was slight opaque as a result of the deposition of yolk at the central part. The ovary became enlarged and spherical when it reached maturity. Then, the ovary became deep yellow. At the spent phase, the ovaries converted to a whitish-yellow color and looked to be a loose sac [25]. At the same time, different stages of ova were found, mostly immature ones with a few ripe ones [27].

Table 4. Mean and standard deviation $( \pm \mathrm{SD})$ of ovary weight $(\mathrm{g})$ and oocyte diameter $(\mathrm{mm})$ of $P$. sophore.

\begin{tabular}{ccccc}
\hline \multirow{2}{*}{ Months } & \multicolumn{4}{c}{ Mean \pm SD } \\
\cline { 2 - 5 } & $\begin{array}{c}\text { Ovary Weight } \\
(\mathbf{g}) \text { in Jessore }\end{array}$ & $\begin{array}{c}\text { Oocyte Diameter } \\
(\mathbf{m m}) \text { in Jessore }\end{array}$ & $\begin{array}{l}\text { Ovary Weight } \\
(\mathbf{g}) \text { in Gazipur }\end{array}$ & $\begin{array}{c}\text { Oocyte Diameter } \\
(\mathbf{m m}) \text { in Gazipur }\end{array}$ \\
\hline January & $0.033 \pm 0.02$ & - & $0.0104 \pm 0.01$ & - \\
February & $0.034 \pm 0.02$ & - & $0.0352 \pm 0.01$ & - \\
March & $0.71 \pm 0.16$ & $0.61 \pm 0.03$ & $0.6758 \pm 0.09$ & $0.71 \pm 0.05$ \\
April & $0.88 \pm 0.26$ & $0.65 \pm 0.04$ & $2.0183 \pm 0.46$ & $0.79 \pm 0.03$ \\
May & $1.126 \pm 0.25$ & $0.678 \pm 0.04$ & $1.842 \pm 0.24$ & $0.72 \pm 0.04$ \\
June & $1.61 \pm 0.28$ & $0.72 \pm 0.04$ & $1.153 \pm 0.24$ & $0.69 \pm 0.03$ \\
July & $1.24 \pm 0.29$ & $0.66 \pm 0.04$ & $0.9478 \pm 0.22$ & $0.65 \pm 0.05$ \\
August & $0.178 \pm 0.07$ & $0.54 \pm 0.03$ & $0.1697 \pm 0.04$ & $0.61 \pm 0.05$ \\
September & $0.166 \pm 0.05$ & $0.51 \pm 0.03$ & $0.1717 \pm 0.08$ & $0.51 \pm 0.04$ \\
\hline
\end{tabular}

\subsection{Histological Observation of Oocyte}

Oocyte development is subdivided into distinct developmental stages. Various authors have studied the gonadal development histologically and identified different stages. The present study showed that oocytes did not develop synchronously. At the mature stage, oocytes were observed in paired ovaries. In the present study, the following maturation stages of oocytes were observed month-wise in female P. sophore (Figure 2).

\subsubsection{Undeveloped Oocyte}

Undeveloped oocyte (UO) is the most immature stage associated with chromatin threads. They are the smallest cell in the germinal epithelium. This stage was observed in the month of March and August (Figure 2, Plate I, VI) beside other stages.

\subsubsection{Early Perinucleolar Stage}

Actual growth of the oocyte begins from this stage. At this stage concomitant with oocyte growth, the nucleus increases in size and multiple nucleoli become located around the periphery of the nucleus. In the early perinucleolar stage (EPNO) oocytes were at the immature stage. This stage was observed in the month of March, mostly for the sample collected from Jessore, which indicates an immature ovary. In the case of Gazipur, beside EPNO, the premature stage was also observed (Figure 2, Plate I A, B).

\subsubsection{Late Perinucleolar Stage}

Enlargement of the oocyte occurs at this stage of oocyte development. A nucleus with a large number of nucleoli was clearly visible. A follicular layer is formed around the oocyte. This marks the beginning of the formation of the chorion. This stage was observed in the month of April. In the case of Gazipur, beside late perinucleorlar stage of oocytes (LPNO), the Yolk-granule stage of the oocytes (YGO) was also found, which indicates a mature oocyte and correlates it with the highest GSI value in April (Figure 2, Plate II, C, D). 


\subsubsection{Yolk Vesicle Stage}

This stage was characterized by the formation of yolk vesicles (YV) in the periphery of the oocytes. Initially they were formed as a single row that appeared colorless when the slides were stained with haematoxylin and eosin. These YV developed as minute bodies but gradually increased in size and number. This stage is available in April for the sample collected from Jessore (Figure 2, Plate II, D), which indicates a maturing oocyte.

\subsubsection{Early Yolk Granule Stage}

The final stage of oocyte development was characterized by the formation of yolk granules in oocytes with fully developed yolk vesicles. This stage was observed in May (Figure 2, Plate III).

\subsubsection{Late Yolk Granule Stage}

The diameter of the oocytes increased simultaneously with the advancement of the yolk granule stage. The number of yolk granules was sharply increasing. They are densely packed and occupy almost the total volume of the oocyte. This stage was observed in the month of June, July, and August (Figure 2, Plates IV, V and VI) when the ovary was fully matured. In August, beside late yolk granule stage (LYG), some undeveloped oocytes were also found (Figure 2, Plate VI).

\subsubsection{Spent Phase}

At this stage, the oocyte enters the ovulatory phase. Different stages of ova were found, mostly immature ones (UO, EPNO) with a few ripe ones. Polar bodies are produced and oocytes are released to the exterior body of the fish. This indicates the spent and resting phases of the ovary. This phase was observed in the month of September (Figure 2, Plate VII).

Information about gonadal development and the spawning season of a species can play a significant role in determining the spawning frequency of its population, which is essential for its management. Ovarian development of $P$. sophore was examined to study the pattern and timing of the growth phase and maturation stages of germ cells in the gonad of a female in Gazipur and Jessore. Seven stages of gradually maturing oocyte were observed, viz., UO, EPNO, LPNO, Yolk vesicle (YVO, early yolk granular stage (EYGO), the late yolk granular stage (LYGO), and the spent phase. These findings agree with the findings of Alam et al. For P. sarana [27].

In the spawning season of Ompok pabo, Alam et al observed the early perinucleolar stage (EP), late perinucleolar stage (LP), YV, EYG, LYG, migratory nucleus stage (MN), premature (PM), and mature (M) stage oocytes in ovary samples from April to June [27]. The most mature stages of oocytes were evident during May to June, indicating the peak breeding season of $O$. pabo. Early stage oocytes were gradually maturing with time and the onset of the breeding season. Fish exclusively in the immature stages (early and late perinucleolar stage oocytes) of maturity were mostly available in the months of March. Yolk vesicle stage oocytes appeared in the month of April. The yolk granular stage was found in the month of May to July. The ovaries contained developing oocytes (UO, EPNO) in September, indicating the spent and resting phases of the ovary. These findings agree with the findings of Mollah, reported for a catfish, Clarias macrocephalus [28]. Histological data revealed that the spawning season of P. sophore starts from March to July, with a peak during April to May in Gazipur, and May to July for the sample collected from Jessore. This result was consistent with the value of GSI of this species of the respected area. A fall in GSI value from its maximum, reduction in the size of gonads (flaccid appearance), and occurrence of the spent fish act as an indicator of one spawning season. On the basis of these parameters, $P$. sophore appear to be a premonsoon and monsoon spawner; i.e., spawns from March to July. Kant et al. reported that $P$. sophore have a slightly longer period of spawning, extending from July to mid-September in Jammu water bodies, which is dissimilar to our findings [22]. This may be due to regional variation as well as other environmental factors. 


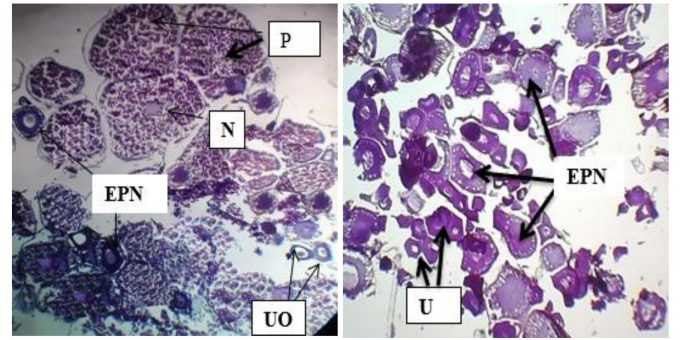

A

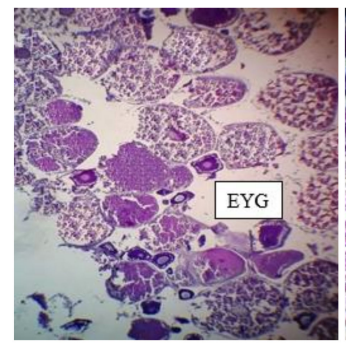

E

Plate-III

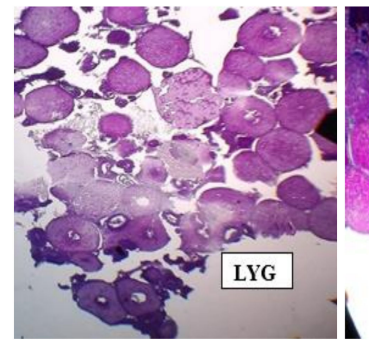

Plate-V

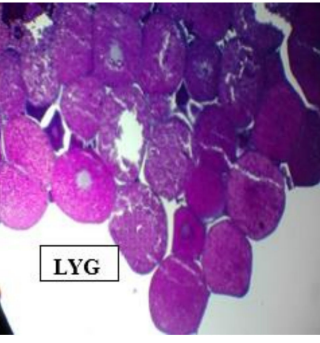

J

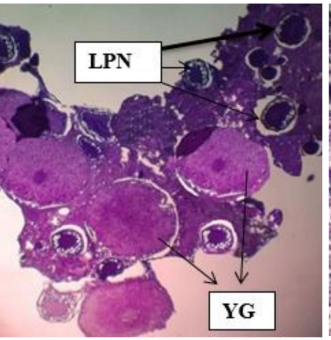

C

Plate-II

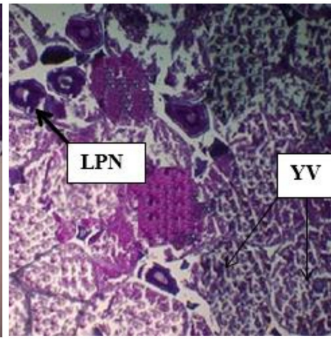

D

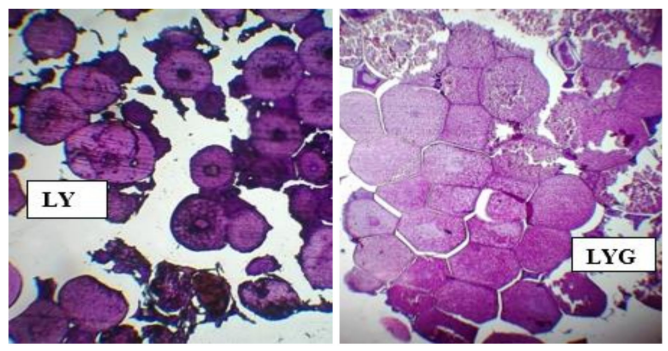

G

Plate-IV

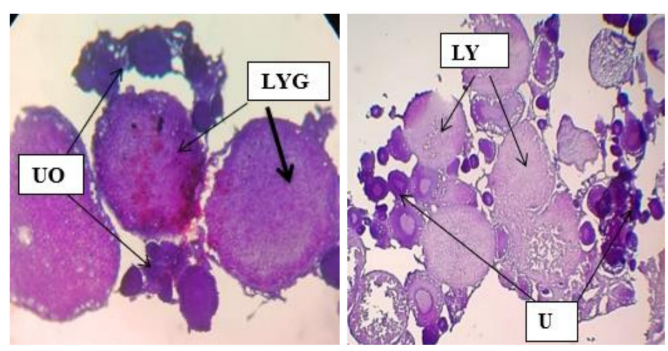

Plate-VI

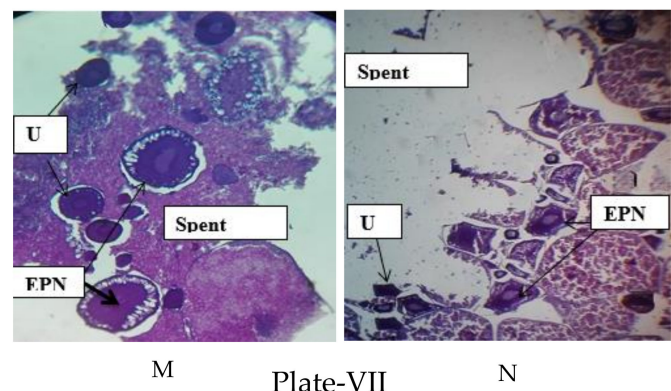

Plate-VII

Figure 2. Histology of ovary of P. sophore. Plate I: Early perinucleolar stage of oocytes (EPNO), Nucleus with nucleoli (N), Undeveloped oocyte (UO), Premature stage (PM) in March in Gazipur (A) and Jessore (B). Plate II: Late perinucleolar stage of oocytes (LPNO), Yolk vesicle stage of oocytes (YVO) and Yolk granule stage of oocytes (YGO) in April in Gazipur (C) and Jessore (D). Plate III: Early Yolk-granule stage of oocytes (EYGO) in May in Gazipur (E) and Jessore (F). Plate IV: Late Yolk-granule stage of oocytes (LYGO) in June in Gazipur (G) and Jessore (H). Plate V: LYGO in July in Gazipur (I) and Jessore (J). Plate VI: LYGO and UO in August in Gazipur (K) and L Jessore (L). Plate VII: Spent phase, EPNO and UO in September in Gazipur (M) and Jessore (N). Hematoxylin \& Eosin stain $\times 200$.

\subsubsection{Maturity Stage of Female Gonads in P. sophore}

All of the collected samples body length, body weight and ovary weight were measured. The ovary weight ranged from $0.0104 \pm 0.01 \mathrm{~g}$ to $2.0183 \pm 0.46 \mathrm{~g}$. On the basis of their reproductive status, 
individual fish were examined and the gonad developmental stages were classified as immature (stage I), Previtellogenesis (stage II), Vitellogenesis (stage III), Maturation (stage IV), spent (stage V) (Table 5).

Table 5. Maturity stage of female gonads in P. sophore.

\begin{tabular}{|c|c|c|}
\hline $\begin{array}{l}\text { Maturity } \\
\text { Stage }\end{array}$ & Period Name & Description \\
\hline I & Immature & $\begin{array}{l}\text { Chromatin threads with no visible eggs. Growth oocyte begins, nucleus } \\
\text { increases in size, and multiple nucleoli become located. }\end{array}$ \\
\hline II & Previtellogenesis & $\begin{array}{l}\text { A follicular layer is formed around the oocyte. Beginning of the } \\
\text { formation of the chorion. }\end{array}$ \\
\hline III & Vitellogenesis & $\begin{array}{l}\text { Formation of yolk vesicle in the periphery of the oocytes. Yolk vesicles } \\
\text { developed as minute bodies but gradually increased in size and number. }\end{array}$ \\
\hline IV & Maturation & $\begin{array}{c}\text { The number of yolk granules was sharply increasing. They are densely } \\
\text { packed and occupy almost the total volume of the oocyte. }\end{array}$ \\
\hline $\mathrm{V}$ & Spent & $\begin{array}{l}\text { At this stage, the oocyte enters the ovulatory phase. Different stages of } \\
\text { ova were found, mostly immature ones with a few ripe ones. Polar bodies } \\
\text { are produced and oocytes are released to the exterior body of fish. }\end{array}$ \\
\hline
\end{tabular}

\subsection{Meteorological Information (Rainfall and Temperature)}

The reproductive activity of $P$. sophore was influenced by environmental factors such as rainfall and temperature. Daily data of temperature and rainfall was collected throughout the study period of Gazipur and Jessore from the meteorological department. In both areas the lowest average temperature was found during February and it gradually increased and became highest during April (Figure 3). In April $\left(30.36^{\circ} \mathrm{C}\right)$ and May $\left(29.05^{\circ} \mathrm{C}\right)$ the temperature of Gazipur was relatively lower than Jessore. At the same time the value of GSI of P. sophore collected from Gazipur was at its peak and higher than Jessore. In June $\left(29.7^{\circ} \mathrm{C}\right)$ and July $\left(28.8^{\circ} \mathrm{C}\right)$, the temperature of Jessore was lower than Gazipur. During this time the value of GSI was also at its peak and higher than Gazipur. High temperature is positively correlated with gonad growth and the related reproductive hormones of fish. But it should be at optimum level.
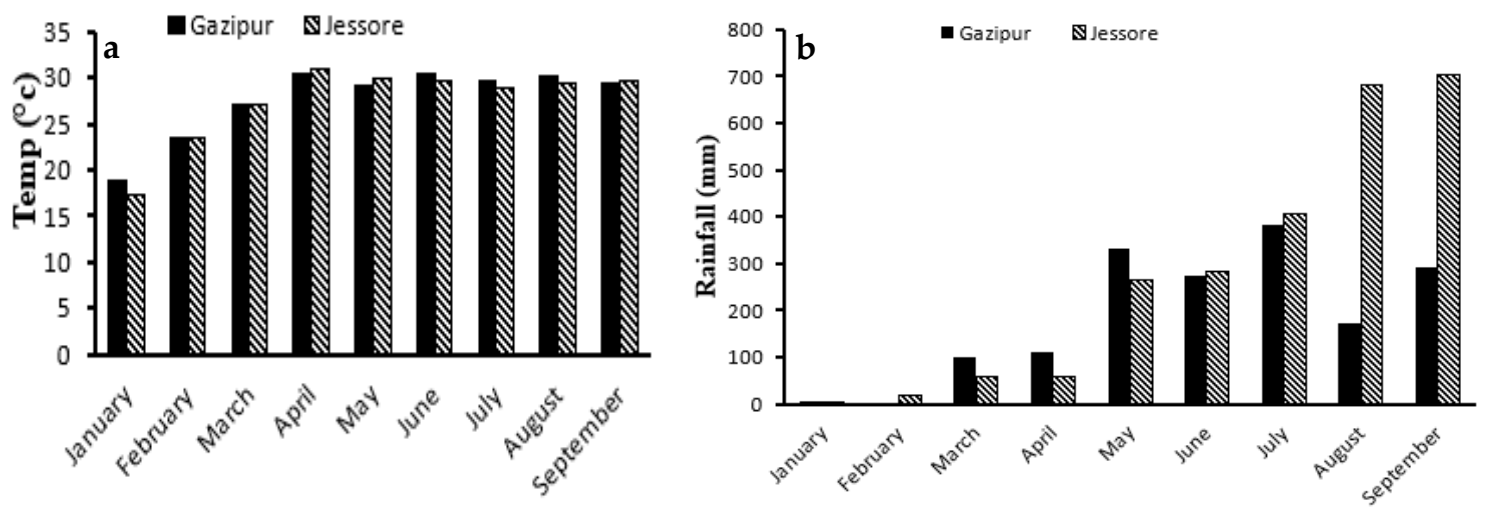

Figure 3. Monthly total Temperature (a) and Rainfall (b) of Gazipur and Jessore.

\section{Materials and Methods}

\subsection{Sample and Data Collection}

Samples of Puntius sophore were collected from Gazipur and Jessore for a period of nine months from January to September 2016. Fifty samples were collected from each of the sampling area. The collected samples were preserved in $10 \%$ formalin. The measurement of length and weight, 
gonad and ova diameter, were conducted in the Post Graduate Laboratory of Fisheries Biology and Aquatic Environment of Bangabandhu Sheikh Mujibur Rahman Agricultural University by using meter scale and electrical balance respectively. The data of rainfall and temperature of those to a particular region were collected from the Meteorological Dept. of Bangladesh. All fishes were handling and caring following the guidelines approved by the Department of Fisheries Biology and Aquatic Environment, Bangabndhu Sheikh Mujibur Rahman Agricultural University (BSMRAU-RMC 165).

\subsection{Gonadosomatic Index (GSI)}

A gonadosomatic index is often used to determine the reproductive cycle of fishes. The GSI is the measure of the relative weight of the gonad with respect to total or somatic weight. The GSI increased with the maturation of fish and reaches to its maximum at the peak period of maturity. The GSI was calculated using the following Formula (1):

$$
\text { GSI }=(\text { Gonad weight } / \text { Body weight }) \times 100
$$

\subsection{Estimation of Fecundity}

The gravimetric method [15] has been used for the estimation of the fecundity of P. sophore. In this method, the ovaries were dissected out by a pair of scissors. The external connective tissues were removed from the surface of each pair of ovaries. The moisture of the ovaries was detached with the help of a blotting paper. The weight of the ovaries of each fish was documented with the help of a digital electronic balance. Then the ovarian part was taken distinctly from the anterior, middle and posterior portions of each ovarian lobe accurately. The number of mature and maturing eggs from each portion was found out separately by actual counting. The mean number of eggs was determined and then multiplied by the total weight of the ovary, which gave the total number of eggs; that is, the fecundity of the respective fish. This was done by the following Formula (2):

$$
\mathrm{F}=\mathrm{N} \times \text { Gonad weight }(\mathrm{g}) / \text { Sample weight }(\mathrm{g})
$$

where, $\mathrm{F}=$ Fecundity of fish; $\mathrm{N}=$ Number of eggs in the sample.

\subsection{Histology of Gonad}

The animal tissue technique method of Humason (1972) was used in this experiment [16]. An automatic tissue processor Leica TP1020 (Leica Biosystem, Nussloch, Germany) was used to determine the histology of the gonad using a series of increasing alcohol concentrations, two changes of xylene, and finally through molten wax (two series). Paraffin-embedded blocks were cut by microtome knife (Microtome machine-Leica Model RM2125RTS, Leica Biosystem, Nussloch, Germany) at 4-5 $\mu \mathrm{m}$ size and the sections were in a water bath (Paraffin Bath-Leica Model HI1210, Leica Biosystem, Heidelberger, Germany) at a temperature of $40{ }^{\circ} \mathrm{C}$. The sections were then placed on a glass slide and kept overnight. Then the sections were cleared with xylene, rehydrated with alcoholic series, and then stained with hematoxylin and eosin stains [16]. After staining, the sections were mounted with Canada balsam and covered by a coverslip and kept on a clean place. The slides were examined under a compound microscope for observation. The photographic records were done simultaneously for future documents of the study.

\subsection{Collection of Meteorological Information (Rainfall and Temperature)}

Secondary data of daily rainfall and temperature of the study area were collected from climate division of meteorological department, Dhaka, Bangladesh, and Department of Agricultural Engineering, BSMRAU, Gazipur. This information was compared with the GSI values, and to observe the influence of temperature and rainfall during fish breeding season. 


\section{Conclusions}

Regarding the environmental temperature, it could be concluded that temperature and rainfall has a direct effect on the gonadal maturation of pool barb. Therefore, we should account for meteorological factors on the gonadal maturation of small indigenous fish species as well as other fish species. This study establishes a strong base for further research on Pool barb with an aim of establishing induced breeding techniques and sustainable management practices in natural water bodies. Moreover, in this way, the small indigenous species of our country can be conserved in nature, which will ultimately help revive aquatic biodiversity.

Author Contributions: S.M.R. was the principal investigator and designed the experiments. T.H. conducted the experiments with the assistance of M.F.H. M.J.A., M.A.S. was the co-investigator and supervised the experiments. M.M. prepared the manuscripts with the help of S.M.R.

Funding: This research received no external funding.

Acknowledgments: This work was supported by the Research Management Committee (RMC) of Bangabandhu Sheikh Mujibur Rahman Agricultural University, Gazipur, Bangladesh, and authors are grateful for their assistance.

Conflicts of Interest: The authors have no conflict of interest.

\section{References}

1. IUCN Bangladesh. Red List of Bangladesh: A Brief on Assessment Result 2015; International Union for Conservation of Nature (IUCN), Bangladesh Country Office: Dhaka, Bangladesh, 2015; p. 24.

2. IUCN Bangladesh. Red List of Bangladesh Volume 5: Freshwater Fishes; International Union for Conservation of Nature (IUCN), Bangladesh Country Office: Dhaka, Bangladesh, 2015; p. xvi+360.

3. Talwar, P.K.; Jhingran, A.G. Inland Fishes of India and Adjacent Countries; Oxford and IBH Publishing Co. Pvt. Ltd.: New Delhi, India, 1991; Volume 2.

4. Petr, T. Coldwater fish and fisheries in Bhutan. In Fish and Fisheries at Higher Altitudes: Asia; Petr, T., Ed.; FAO Fisheries Technical Paper No. 385; FAO: Rome, Italy, 1999; pp. 6-12.

5. Menon, A.G.K. Checklist_-Fresh Water Fishes of India; Zoological Survey of India, Occasional Paper No. 175; Miscellaneous Publications: Delhi, India, 1999; 366p.

6. Craig, J.F.; Halls, A.S.; Barr, J.J.F.; Bean, C.W. The Bangladesh floodplain fisheries. Fish. Res. 2004, 66, $271-286$. [CrossRef]

7. Food and Agriculture Organization (FAO). Management Guideline for Asian Floodplain River Fisheries. Part 2: Summary of DFID Research; FAO: Rome, Italy, 1996; pp. 32-34.

8. Samad, M.A.; Galib, S.M.; Flowra, F.A. Fish drying in Chalan Beel areas, Bangladesh. J. Sci. Ind. Res. 2009, 44, 461-466.

9. Shafi, M.; Quddus, M.M.A. Bangladesher Matshya Sampad (Fishery Resources of Bangladesh); Bangla Academy: Dhaka, Bangladesh, 1982; 444p.

10. Rahman, A.K.A. Freshwater fishes of Bangladesh, 2nd ed.; Zoological Society of Bangladesh, Department of Zoology, University of Dhaka: Dhaka, Bangladesh, 2005; pp. 66-67.

11. Roos, N.; Leth, T.; Jakobsen, J.; Thilsted, S.H. High vitamin A content in some small indigenous fish species in Bangladesh: Perspectives for food-based strategies to reduce vitamin A deficiency. Int. J. Food Sci. Nutr. 2002, 53, 425-437. [CrossRef] [PubMed]

12. Thilsted, S.H. The importance of small indigenous fish species for improved human nutrition in rural Bangladesh. In Small Indigenous Species of Fish in Bangladesh; Wahab, M.A., Thilsted, S.H., Hoq, M.E., Eds.; Bangladesh Agricultural University: Mymensingh, Bangladesh, 2003; 116p.

13. Thilsted, S.H.; Roos, N.; Hassan, N. The role of small indigenous fish species in food and nutrition security in Bangladesh. Naga ICLARM Q. 1997, 20, 82-84.

14. Froese, R.; Pauly, D. FishBase 2011. World Wide Web Electronic Publication. 2011. Available online: http:/ / www.fishbase.org (accessed on 12 December 2016).

15. Lagler, K.F. Enumeration of fish eggs. In Freshwater Fishery Biology, 2nd ed.; W.M.C. Brown Co.: Dubuque, IA, USA, 1956; pp. 106-110.

16. Wootton, R.J. Ecology of Teleost Fishes; Chapman and Hall: London, UK, 1995. 
17. Choudhury, T.G.; Singh, S.K.; Baruah, A.; Das, A.; Parhi, A.; Bhattacharjee, P.; Biswas, P. Reproductive Features of Puntius sophore (Hamilton 1822) from Rivers of Tripura, India. Fish. Technol. 2015, 52, 140-144.

18. Chandrasoma, J.; De-Silva, S.S. Reproductive biology of Puntius sarana, an indigenous species and Tilapia rendalli, an exotic, in an ancient man-made lake in Sri Lanka. Fish. Manag. 1981, 12, 17-28. [CrossRef]

19. Hossain, M.A.R.; Wahab, M.A. Bangladesher Nadir Machher Jibaboichitra (in Bengali); Matshya Saptaha Songkolan (Proceeding published in Fisheries Week, 2012); Department of Fisheries (DoF): Dhaka, Bangladesh, 2012.

20. Agarwal, A. Studies on the Karyotype and Histological Changes in Gonads of Some Fishes of Jammu and Kashmir. Ph.D. Thesis, University of Jammu, Jammu, India, 1982.

21. Kant, K.J.; Gupta, K.; Langer, S. Fecundity in fish Puntius sophore and relationship of fecundity with fish length, fish weight and ovary weight from Jammu water bodies J and K (India). Int. J. Fish. Aquac. Sci. 2016, $6,99-110$.

22. Tracey, S.R.; Lyle, J.; Haddon, M. Reproductive biology and per-recruit analyses of striped trumpeter (Latris lineata) from Tasmania, Australia: Implications for management. Fish. Res. 2007, 84, 358-368. [CrossRef]

23. Tareque, A.M.H.B.; Biswas, B.; Hossain, M.S.; Rahman, M.M.; Rahman, M.M. Some aspects of Puntius sophore (Hamilton) collected from the Mouri River, Khula, Bangladesh. Bangladesh Res. Publ. J. 2009, 2, 406-422.

24. Bithy, K.; Miah, M.I.; Haque, M.S.; Hasan, K.R.; Islam, M.F. Estimation of the Fecundity of Jat Puti, Puntius sophore (Hamilton). J. Environ. Sci. Nat. Resour. 2012, 5, 295-300. [CrossRef]

25. Das, D.R. A Study on the Fecundity of Featherback, Notopterus notopterus (pallas) from two Different Sources (Pond and Beel). Master's Thesis, Department of Aquaculture, Bangladesh Agricultural University, Mymensingh, Bangladesh, 1998.

26. Chakraborty, B.K.; Mirza, Z.A.; Miah, M.I.; Habib, M.A.B.; Chakraborty, A. Reproductive Cycle of the Endangered Sarpunti, Puntius sarana (Hamilton, 1822) in Bangladesh. Asian Fish. Sci. 2007, 20, 145-164.

27. Alam, M.M.; Ahmad, S.; Hussain, M.A. Ovarian development and reproductive cycle of two freshwater barbs, Puntius sophore and Puntius ticto. Front. Biol. Life Sci. 2014, 2, 12-15. [CrossRef]

28. Mollah, M.F.A. Cyclic changes in the ovary of freshwater catfish, Clarias macrocephalus (Gunther). Indian J. Fish. 1986, 33, 54-65.

(C) 2018 by the authors. Licensee MDPI, Basel, Switzerland. This article is an open access article distributed under the terms and conditions of the Creative Commons Attribution (CC BY) license (http://creativecommons.org/licenses/by/4.0/). 